\title{
Genetic Divergence Studies in Finger Millet [Eleusine coracana (L.) Gaertn.]
}

\author{
Sarjansinh D. Devaliya*, Manju Singh and C.G. Intawala
}

\author{
Department of Genetics and Plant Breeding, N. M. College of Agriculture, \\ Navsari Agricultural University, Navsari- 396 450, Gujarat, India \\ *Corresponding author
}

\begin{tabular}{|c|c|}
\hline & A B S T R A C T \\
\hline & mprised 68 diverse genotypes of finger millet \\
\hline Keywords & (Eleusine coracana (L.) Gaertn). The data on 13 quantitative traits were recorded \\
\hline $\begin{array}{l}\text { Finger millet, Genetic } \\
\text { divergence and } \mathrm{D}^{2} \\
\text { statistic. }\end{array}$ & $\begin{array}{l}\text { to assess the magnitude of genetic divergence for yield and yield contributing } \\
\text { traits. In the present investigation, } \mathrm{D}^{2} \text { statistic indicated that the genotypes studied } \\
\text { were genetically diverse. Based on genetic distances the } 8 \text { genotypes under study }\end{array}$ \\
\hline Article Info & were grouped into eight clusters. Cluster I contains highest 60 genotypes, followed \\
\hline $\begin{array}{l}\text { Accepted: } \\
17 \text { September } 2017 \\
\text { Available Online: } \\
10 \text { November } 2017\end{array}$ & $\begin{array}{l}\text { clusters were solitary. The maximum inter-cluster distance was observed between } \\
\text { cluster-VIII and III. In overall, } \mathrm{D}^{2} \text { analysis suggested genotypes belonging to the } \\
\text { distinct cluster (VIII and III) could be used in hybridization programme } \\
\text { forenhance the productivity of finger millet. }\end{array}$ \\
\hline
\end{tabular}

\section{Introduction}

Finger millet (Eleusine coracana L.) ranks third among millets after sorghum and pearl millet. Finger millet is crop of antiquity and known for their suitability to dry lands, hill and tribal agriculture. It is cultivated mostly as a rainfed crop in India for its valued food grains and its adaptability to wide range of geographical areas and agro-ecological diversity, mostly continent in Africa and Asia. India is a major producer of finger millet in Asia with an area of 1193.70 thousand hectares with production of 1982.90 thousand tonnes and productivity of $1661.00 \mathrm{~kg}$ per hectare (Anon., 2014). The major finger millet growing states include Karnataka, Tamil Nadu, Andhra Pradesh, Orissa, Maharashtra, Uttarakhand, West Bengal and
Gujarat. The basic information on the existence of genetic variability and diversity in a population and the relationship between different traits is essential for any successful plant breeding programme. Genetic improvement through conventional breeding approaches depends mainly on the availability of diverse germplasm and presence of enormous genetic variability. The characterization and evaluation are the important pre-requisites for effective utilization of germplasm and also to identify sources of useful genes and superior genotypes. Among the multivariate procedures, Mahalanobis (1936) generalized distance $\left(D^{2}\right)$ has been used extensively. Attempt has been made in this study to assess 
the nature and magnitude of genetic divergence for yield and its component in finger millet and also to identify divergent parents from distantly related clusters for suitable hybridization.

\section{Materials and Methods}

Thirteen yield contributing characteristics were taken to assess the magnitude of genetic divergence for 68 genotypes of finger millet. The experimental material consisted 68 finger millet genotypes grown in randomized block design with three replications at Hill Millet Research Station, Waghai (Gujarat) during Kharif, 2015. Each entry was grown in 1.5 meter row with spacing of $30 \mathrm{~cm}$ between the rows and $10 \mathrm{~cm}$ within the plants. Five randomly selected plants from each genotypes in each replications were used to record observations on plant height, number of productive tillers per plant, numbers of fingers per ear, main ear head length, test weight, grain yield per plant, straw yield per plant and harvest index except 50 per cent flowering and days to maturity. Days to 50 per cent flowering and days to maturity was noted on single row basis. The mean of five plants was subjected to statistical analysis, data were statistical analyzed to estimate genetic divergence was estimated by multivariate analysis using Mahalanobis (1936) $\mathrm{D}^{2}$ statistic as described by Rao (1952). On the basis of $\mathrm{D}^{2}$ values genotypes were grouped into different clusters according to Tocher's method given by Rao (1952).

\section{Results and Discussion}

Genetic diversity studies provide basic information regarding the genetic parameters of the genotypes based on which breeding methods are constituted for further crop improvement. These studies are also helpful to know about the nature and extent of diversity that can be attributed to different causes, sensitivity of crop to environment and genetic divergence.

$\mathrm{D}^{2}$ statistics, a concept developed by Mahalanobis (1936) is important tool to plant breeder to classify the genotypes into different groups based on genetic divergence between them.

In the present study magnitude of $\mathrm{D}^{2}$ Values 68 genotypes were grouped into eight clusters (Table 1). Cluster Ihad the maximum of 60 genotypes each followed by cluster VII (2) while the remaining six clusters were solitary. The genotypes WN-586, WN-622, WN-588, $\mathrm{WN}-591, \mathrm{WN}-616$ and $\mathrm{WN}-595$ formed single stocked cluster indicating wide diversity from set, as well as from each other. In finger millet, similar results was found by Karad and Patil (2013), Anantharaju and Meenakshiganesan (2008), Das et al., (2013) and Suryanarayana et al., (2014)

Intra and inter cluster $\mathrm{D}^{2}$ values were worked out using $\mathrm{D}^{2}$ values from divergence analysis (Table 2). A study of the data revealed that the inter-cluster distance (D) ranged from 3.81 to 12.43 . The maximum inter-cluster distance was observed between cluster-VIII and III $\left(D^{2}=12.43\right)$ followed by those between cluster-VII and IV $\left(\mathrm{D}^{2}=10.87\right)$. The minimum inter-cluster distance was observed between cluster-IV and II $\left(\mathrm{D}^{2}=3.81\right)$ followed by the cluster-V and II $\left(D^{2}=5.41\right)$. High value of inter-cluster distance points out towards high amount of diversity between the clusters involved.

Hence, from the above discussion we can conclude that the genotypes from the cluster VIII and III were more divergent than any other cluster. Hence, the genotypes belonging to the distinct cluster (VIII and III) could be used in hybridization programme for obtaining a wide spectrum of variation among the segregrants. 
Table.1 The distribution of 68 genotypes of Finger millet into eight different clusters on the basis of Mahalanobis $D^{2}$ Statistics

\begin{tabular}{|c|c|c|}
\hline Cluster & No of genotypes & Genotypes \\
\hline 1 & 60 & $\begin{array}{l}\text { WWN-40, WWN-41, WWN-57, WN-625, WWN-50, WN-619, WN-617, WN-630, } \\
\text { WWN-47, WN-612, WWN-49, WWN-38, WN-596, WN-618, WN-623, WN-594, } \\
\text { WN-605, WWN-45, WN-624, WN-606, WWN-52, WN-592, WWN-56, WWN-48, } \\
\text { WN-621, GN-4, WN-587, WWN-53, WN-593, WN-603, WN-601, WWN-43, WN- } \\
\text { 610, WWN-46, GNN-6, WWN-39, GN-5, WN-609 WWN-54, WWN-55, WN-614, } \\
\text { WN-604, WN-589, WN-590, WN-629, WWN-51, WN-607, WN-628, WN-626, WN- } \\
\text { 627, WN-608, WN-599, WN-611, WN-620, WN-598, WN-597, WN-602, WN-60, } \\
\text { WN-615 }\end{array}$ \\
\hline 3 & 1 & WN-622 \\
\hline 4 & 1 & WN-588 \\
\hline 5 & 1 & WN-591 \\
\hline 6 & 1 & WN-616 \\
\hline 7 & 2 & WWN-42, WWN-44 \\
\hline 8 & 1 & WN-595 \\
\hline
\end{tabular}

Table.2 Average Intra and Inter - cluster $\left(D^{2}\right)$ values for 68 genotypes of Finger millet

\begin{tabular}{|c|c|c|c|c|c|c|c|c|}
\hline Cluster & $\mathbf{1}$ & $\mathbf{2}$ & $\mathbf{3}$ & $\mathbf{4}$ & $\mathbf{5}$ & $\mathbf{6}$ & $\mathbf{7}$ & $\mathbf{8}$ \\
\hline $\mathbf{1}$ & 4.78 & 6.31 & 6.11 & 6.33 & 6.79 & 7.50 & 8.96 & 9.16 \\
\hline $\mathbf{2}$ & & 0.00 & 8.42 & 3.81 & 5.41 & 7.15 & 10.39 & 7.09 \\
\hline $\mathbf{3}$ & & & 0.00 & 8.95 & 8.92 & 8.69 & 10.13 & 12.43 \\
\hline $\mathbf{5}$ & & & & 0.00 & 5.55 & 6.72 & 10.87 & 7.64 \\
\hline $\mathbf{6}$ & & & & & 0.00 & 5.71 & 9.50 & 6.45 \\
\hline $\mathbf{7}$ & & & & & & 0.00 & 8.99 & 7.66 \\
\hline $\mathbf{8}$ & & & & & & & 4.88 & 8.60 \\
\hline
\end{tabular}


Table.3 Cluster means for thirteen characters in 68 genotypes of Finger millet

\begin{tabular}{|c|c|c|c|c|c|c|c|c|c|c|c|c|c|}
\hline $\begin{array}{c}\text { Cluster } \\
\text { Number }\end{array}$ & $\begin{array}{c}\text { Days to } \\
50 \% \\
\text { flowering }\end{array}$ & $\begin{array}{l}\text { Days to } \\
\text { maturity }\end{array}$ & $\begin{array}{c}\text { Plant } \\
\text { height } \\
(\mathrm{cm})\end{array}$ & $\begin{array}{c}\text { Number of } \\
\text { productive } \\
\text { tillers per } \\
\text { plant }\end{array}$ & $\begin{array}{l}\text { Number of } \\
\text { fingers per } \\
\text { ear }\end{array}$ & $\begin{array}{l}\text { Main } \\
\text { earhead } \\
\text { length } \\
(\mathrm{cm})\end{array}$ & $\begin{array}{c}\text { 1000- } \\
\text { Grain } \\
\text { weight } \\
\text { (g) }\end{array}$ & $\begin{array}{c}\text { Grain } \\
\text { yield per } \\
\text { plant (g) }\end{array}$ & $\begin{array}{c}\text { Straw } \\
\text { yield } \\
\text { per } \\
\text { plant } \\
\text { (g) }\end{array}$ & $\begin{array}{c}\text { Harvest } \\
\text { index (\%) }\end{array}$ & $\begin{array}{c}\text { Protein } \\
\text { content } \\
(\%)\end{array}$ & $\begin{array}{c}\text { Iron } \\
\text { content } \\
(\mathbf{p p m})\end{array}$ & $\begin{array}{c}\text { Calcium } \\
\text { content } \\
(\%)\end{array}$ \\
\hline 1 & 81.09 & 118.59 & 103.66 & 2.14 & 8.59 & 9.24 & 2.67 & 7.34 & 25.75 & 22.30 & 6.91 & 52.23 & 0.33 \\
\hline 2 & 70.67 & 107.00 & 100.00 & 2.40 & 7.53 & 6.23 & 2.59 & 7.13 & 24.47 & 22.57 & 6.33 & 43.93 & 0.32 \\
\hline 3 & 73.33 & 109.00 & 103.53 & 2.60 & 10.87 & 9.99 & 3.02 & 9.61 & 30.90 & 23.01 & 6.98 & 55.47 & 0.31 \\
\hline 4 & 72.67 & 109.67 & 107.33 & 1.87 & 5.53 & 9.13 & 2.84 & 6.00 & 21.10 & 22.16 & 6.35 & 43.33 & 0.34 \\
\hline 5 & 83.33 & 120.33 & 113.93 & 2.53 & 7.67 & 8.12 & 2.68 & 9.34 & 30.90 & 24.59 & 7.04 & 41.00 & 0.32 \\
\hline 6 & 72.67 & 108.67 & 92.40 & 1.67 & 8.80 & 10.02 & 3.06 & 6.37 & 21.25 & 25.06 & 7.25 & 40.40 & 0.30 \\
\hline 7 & 81.33 & 119.17 & 96.87 & 2.70 & 7.93 & 7.78 & 3.05 & 8.45 & 31.42 & 25.80 & 7.01 & 55.93 & 0.34 \\
\hline 8 & 92.67 & 131.00 & 91.87 & 2.27 & 5.80 & 5.47 & 2.81 & 5.93 & 21.00 & 25.44 & 6.83 & 42.00 & 0.33 \\
\hline
\end{tabular}

Note: Bold figures are minimum and maximum values

Table.4 Contribution of thirteen characters under study to the total divergence

\begin{tabular}{|c|c|c|c|}
\hline Sr. No & Character & No. of times ranked first & \% contribution towards divergence \\
\hline 1 & Days to $50 \%$ flowering & 108 & $4.74 \%$ \\
\hline 2 & Days to maturity & 19 & $0.83 \%$ \\
\hline 3 & Plant height $(\mathrm{cm})$ & 57 & $2.50 \%$ \\
\hline 4 & Number of productive tillers per plant & 163 & $7.16 \%$ \\
\hline 5 & Number of fingers per ear & 56 & $2.46 \%$ \\
\hline 6 & Main earhead length $(\mathrm{cm})$ & 354 & $15.54 \%$ \\
\hline 7 & 1000-Grain weight $(\mathrm{g})$ & 192 & $8.43 \%$ \\
\hline 8 & Grain yield per plant (g) & 13 & $0.57 \%$ \\
\hline 9 & Straw yield per plant $(\mathrm{g})$ & 1 & $0.04 \%$ \\
\hline 10 & Harvest index $(\%)$ & 217 & $9.53 \%$ \\
\hline 11 & Protein content $(\%)$ & 124 & $5.44 \%$ \\
\hline 12 & Iron content (ppm) & 924 & $40.56 \%$ \\
\hline 13 & Calcium content (\%) & 50 & $2.19 \%$ \\
\hline \multicolumn{2}{|r|}{ TOTAL } & 2278 & $100 \%$ \\
\hline
\end{tabular}


Intra-cluster distance (D) ranged from 4.78 to 4.88. At intra-cluster level, cluster-VIII $\left(\mathrm{D}^{2}=\right.$ 4.88) had the highest value. The minimum intra-cluster distance was observed in clusterI $\left(\mathrm{D}^{2}=4.78\right)$ which included sixty genotypes with less diversity among them. The intracluster distance within cluster II, III, IV, V, VI and VIII were zero (0) because these clusters were composed of only single genotype.

The cluster means for various characters are presented in Table 3. Cluster VII had maximum mean value for number of productive tillers per plant (2.70), straw yield per plant (31.42), harvest index (25.80), iron content (55.93) and calcium content (0.34). Cluster VI had maximum mean value for main earhead length (10.02), test weight (3.06) and protein content (7.25). Cluster VIII exhibited early flowering (70.67) and early maturing (107.00) genotypes, whereas Cluster III recorded highest mean values for the characters grain yield per plant (9.61) and number of fingers per ear (10.87) and cluster $\mathrm{V}$ exhibited maximum plant height (113.93). It is observed that number of cluster contained at least one genotype with all the desirable traits, which ruled out the possibility of selecting directly one genotype for immediate use. Therefore, hybridization between the selected genotypes from divergent clusters is essential to judiciously combine all the targeted traits.

It could be concluded that high yielding genotypes coupled with other desirable physiological traits like, productive tillers per plant, number of fingers per ear, main ear head length, straw yield per plant, grain yield per plant, test weight, protein content, iron content and calcium content could be selected as parents for hybridization programme from cluster VI (WN-616), VII (WWN-42, WWN44) and cluster III (WN-622), whereas the genotypes WN-586 were selected from
Cluster II for earliness in days to flowering and days to maturity based on lowest cluster mean. Inter crossing genotypes from these clusters might results in hybrids having high vigor and may further results in wide array of genetic variability for exercising effective selection.

The character iron content (40.56\%) contributed maximum towards divergence followed by main earhead length (15.54 per cent), harvest index (9.53 per cent), test weight (8.43 per cent) and number of productive tillers per plant (7.16 per cent), while calcium content ( 2.19 per cent), days to maturity ( 0.83 per cent), grain yield per plant $(0.57$ per cent $)$ and straw yield per plant $(0.04$ per cent) contributed very low towards divergence (Table 4).

\section{References}

Anantharaju, P. and Meenakshiganesan, N. 2008. Genetic divergence studies in finger millet (Eleusine coracana (L.) Gaertn.). Indian Journal of Agricultural Research, 42(2): 120-123.

Anonymous. 2014. Annual report 2013-2014, Department of Agriculture and Cooperation, Ministry of Agriculture, Government of India Krishi Bhawan, New Delhi-110 001 March, 2015.

Das, R., Sujatha, M., Pandravada, S. R., and Sivasankar, A. 2013. Genetic divergence studies in finger millet (Eleusine coracana (L.) Gaertn.) germplasm. Trends in Biosciences, 6(4): 373-376.

Karad, S. R. and Patil, J. V. 2013. Assessment of genetic diversity among of finger millet (Eleusine coracana (L.) genotypes. International Journal of Integrative sciences, Innovation and Technology Journal, 2(4): 37-43

Mahalanobis's P. C. 1936. On the generalized distance in statistics. Proc. National 
Institute of Science, (India), 2: 49-55.

Rao, C. R. 1952. "Advanced Statistical Methods in Biometrical Research", John Willy and Sons, Inc., New York, pp. 390.

Suryanarayana, L., Sekhar, D. and Rao, N. V.
2014. Genetic variability and divergence studies in finger millet (Eleusine coracana (L.) Gaertn.). International Journal of Current Microbiology and Applied Sciences, 3(4): 931-936.

\section{How to cite this article:}

Sarjansinh D. Devaliya, Manju Singh and Intawala, C.G. 2017. Genetic Divergence Studies in Finger Millet [Eleusine coracana (L.) Gaertn.]. Int.J.Curr.Microbiol.App.Sci. 6(11): 20172022. doi: https://doi.org/10.20546/ijcmas.2017.611.240 